\title{
Early diagenesis of the lower Vectis Formation, Wealden Group (Lower Cretaceous, Barremian), Sandown, Isle of Wight
}

\author{
J.M. Huggett ${ }^{1}$, A.S. Gale ${ }^{2}$ and C. Hazell ${ }^{3}$ \\ ${ }^{1}$ Petroclays Ltd., the Oast, Sandy Cross, Heathfield, E Sussex, TN21 8QP, UK \\ ${ }^{2}$ School of Earth \& Environmental Sciences, University of Portsmouth, Burnaby Rd., Portsmouth, \\ Hampshire, PO1 3QL UK.
}

${ }^{3}$ Northumbria University, Sutherland Building, Newcastle-upon-Tyne, NE1 8ST

\begin{abstract}
The Vectis Formation was deposited in a restricted lagoonal environment that periodically dried up, as indicated by the presence of desiccation surfaces. The fauna indicates that salinities fluctuated significantly during deposition, from fresh to brackish-marine. Pre-burial berthierine-rich clay replaced faecal pellets in the sediment, infilling desiccation cracks, during re-flooding of the lagoon. Concretions formed by early pyrite and apatite cementation during initial burial in lake sediment, with organic debris of fish and wood, acting as nuclei and a trigger for cementation. With subsequent partial or complete exhumation oxidation of the pyrite occurred, prior to cementation by Mn siderite. All further concretion cementation occurred within the oxic to sub-oxic diagenetic zones. Textural relationships indicate that commonly occurring baryte formed after pyrite oxidation and represents the last diagenetic mineral phase.
\end{abstract}

Geological background

The Vectis Formation in the Isle of Wight comprises up to $65 \mathrm{~m}$ of dark silty clays and subordinate sandstones, and rests with a sharply defined surface upon the pedogenically modified, mottled, slits and clays of the underlying Wessex Formation (White, 1921; Daley and Stewart, 1979; Insole et al., 1998; Radley and Allen, 2012), (Figs. 2-4). Together, the Wessex and Vectis Formations make up the Wealden Group as exposed on the Isle of Wight. The formation is divided into three members; the lowest, the Cowleaze Chine Member (7-10 m), comprises dark silty clays containing bivalves (Filosina) in the lower part. The middle member, the Barnes High Member, is a sandstone (2-7m), which has been interpreted by Stewart (1981) as a delta built into the Vectis lagoon. The uppermost Shepherd's Chine Member $(35 \mathrm{~m})$ is made up of clays containing thin shelly limestones (Stewart 1981; Radley et al. 1997). The Vectis Formation does not yield age-diagnostic fossils, but magnetostratigraphy (Kerth and Hailwood 1988) can be interpreted as recording the Barremian-Aptian ( $\mathrm{MO}$ ) boundary at the level of the Barnes High Member. The Cowleaze Chine Member is therefore of late Barremian age. 
At Yaverland, the base of the Vectis Formation and Cowleaze Chine Member (Figs. 2-4) rests with marked contrast upon a yellow-grey mottled palaeosol, containing sideritic concretions, which forms the uppermost part of the Wessex Formation. The Cowleaze Chine Member here comprises dark, slightly silty clays containing bivalves (Filosina) in beds at the base (Fig. 2, 1-1.1 m), and higher levels (Fig. 2, 2.6$3 \mathrm{~m}$ ). A well-marked desiccation surface $0.8 \mathrm{~m}$ above the base (Figs. 2 and 5) displays large polygons infilled with darker, greenish clay, and a concentration of semi-articulated and disarticulated bones and scales of the fish Lepidotes rests upon the surface (Gale 2012 Fig. 18.6). The fish bed is overlain by a thin lag $(0.1 \mathrm{~m})$ made up of pellets of berthierine-rich clay (Fig. 5). The overlying part of the Cowleaze Chine Member contains silty beds and lenses, pyritic concretions, and a $0.2 \mathrm{~m}$ thick siderite cemented siltstone is full of moulds of the gastropod Viviparus (Fig. 2, 6.2-6.4 m). A desiccated surface, with less sharply defined polygons, is present above this bed (Fig. 2). Rare phosphatic nodules are light grey, ovoid in shape $(10 \times 5 \mathrm{~cm})$ and have a core of fish bone debris. The broken surfaces commonly show dense small white patches, $1-2 \mathrm{~mm}$ in diameter. Beach- worn fragments of these distinctive nodules from the Vectis Formation are well known, but previously only described in an unpublished thesis (Hazell, 2014).

Palaeoenvironment.

The Vectis Formation was deposited in a lagoonal environment, adjacent to the fault-bounded northern margin of the Channel Basin (Radley et al. 1997; Stewart et al. 1991), from which Jurassic fossils and lithoclasts were derived into the Shepherd's Chine Member. Although the lagoon evidently dried up periodically, as shown by desiccation surfaces (Fig. 7), no evidence of palaeosol development is evident, and plant roots are absent; therefore, desiccation was relatively short lived. Salinities fluctuated significantly during deposition of the unit (Stewart et al. 1991); the abundance of the bivalve Filosina indicates a brackish salinity of about 20 ppt (Radley et al. 1997) for part of the succession. However, the presence of abundant freshwater gastropods (Vivparus, Fig. 4) and bivalves (unionids) in some beds indicates significant, if short-lived freshwater imput. One level in the Shepherd's Chine Member contains ostracods and bivalves indicative of salinities close to fully marine conditions (ASG pers obs).

\section{Sampling}

The locations of phosphatic nodules and clay samples are marked on Fig. 2. Phosphatic nodule A (Fig. 6) was found loose and is probably derived from a horizon within the Cowleaze Chine Member. The form of preservation and implications for how this occurred suggests an environment similar to the desiccated fish bed horizon at Sandown Bay (Fig. 2 sample position 1). Phosphatic nodule B originated 
from the $4 \mathrm{~m}$ level in Fig. 2. Samples of green clay were obtained from between polygons (V1), infilling desiccation cracks, immediately below the fish bed (V2) and from a reworked clay lag (V3), Fig. 2.

Methods

Samples of the phosphatic (two) and sideritic nodules (one) plus three samples of the green clay were initially examined in hand specimen, and then in thin-section. Polished thin sections were imaged in a Zeiss EVO; energy dispersive Spectra (EDS) were collected using an Oxford Instruments INCA detector. The mineralogy of the green clays was determined by XRD, using a Siemens PSD X-ray diffractometer with Ni-filtered CuKa radiation. The two samples containing green granules (V1 \& V2) were sieved using a $63 \mu \mathrm{m}$ sieve to separate the granules $(>63 \mu \mathrm{m})$ from the fine detrital matrix. The granules were then crushed and the $<2 \mu \mathrm{m}$ fraction extracted by centrifugation. The $2 \mu \mathrm{m}$ fraction was deposited onto clay tiles for analysis. The clay tiles were scanned using a $0.02^{\circ}$ step width, with $0.2 \mathrm{~mm}$ slits from 2 to $40^{\circ} 2 \theta$. The tiles were scanned again after treating with glycol, after heating at $400^{\circ} \mathrm{C}$ for 4 hours, and after heating at $550^{\circ} \mathrm{C}$, also for 4 hours.

\section{Concretion Petrology}

Nodule sample A was ovoid, and approximately $15 \mathrm{~cm}$ in length and $7 \mathrm{~cm}$ in diameter. The core (Fig. 6) comprises a dense mat of $1-2 \mathrm{~mm}$ spherical white blebs of barite. Nodule B is $30 \mathrm{~cm}$ long by $20 \mathrm{~cm}$ diameter and comprises an irregular mass of dark fish bones and tiny white spheres of apatite. Apatite is volumetrically the principal cement in both the fish bone and wood at the core of both nodules, and in the enclosing silty clay-rich outer part of the nodules. The apatite preserves syn-sedimentary closed fractures in the sediment (Fig. 8A). Haversian canal cavities are cemented by cryptocrystalline apatite mimicking a previous fibrous structure (Fig. 8B). In turn, the fibres of apatite have been partly pseudomorphed by baryte (Fig. 8B).

Pyrite is present on the outer surface of fish bones and scales, and has cemented the walls of the haversian canal cavities in bones (Fig. 8C). Pyrite is present both as microcrystalline aggregates and as larger crystals that were probably cubes prior to partial replacement by baryte (Fig. 8D). The microcrystalline pyrite is pitted, (Fig. 8E); this may be a consequence of partial oxidation. Pyrite in fractures is overgrown or replaced by baryte. $\mathrm{Mn}$ siderite with a mean composition of $\left(\mathrm{Ca}_{0}\right.$. 
$\left.{ }_{1} \mathrm{Mn}_{0.14} \mathrm{Fe}_{0.75}\right) \mathrm{CO}_{3}$ has overgrown pyrite in nodule $\mathrm{B}(\mathrm{Fig}$. 8F). Trace sphalerite is also present but textural relationships with other minerals are equivocal.

Baryte occurs as radial aggregates of needle-shaped crystals that have replaced apatite (Figs. 7B \& C), as poikilotopic anhedral crystals (Fig. 8E) and cementing fractures within the nodule (Fig. 8F). The poikilotopic baryte has enclosed both siderite and pyrite, and partially cemented fractures containing injected? Sediment (Fig. 8A). The baryte has a small $(<1.5 \%)$ proportion of $\mathrm{Sr}^{2+}$ substitution for $\mathrm{Ba}^{2+}$.

\section{Clay Granule Petrology}

XRD analysis of the granules indicates that the green clay is dominated by a clay mineral of the serpentine group, probably berthierine. Samples V1 and V2 (from between polygons and infilling cracks respectively) contain ovoid granules $200-300 \mu \mathrm{m}$ long comprising green clay with minor silt-size quartz (Fig. 9A). Some granules are partially replaced by siderite (Fig. 9A). The granules are predominantly entire, and undamaged by reworking. EDS analysis indicates that the clay contains $\mathrm{Fe}, \mathrm{Si}, \mathrm{Al}$ and minor Mg. Sample V3, from the clay lag comprises quartz sand with pore-filling and grain-coating Fe-rich clay. The V3 clay has the same composition as the clay granules in V1 \& V2 (Fig. 9B).

\section{Discussion}

The characteristic depth and chemical diagenetic zones for the authigenic minerals encountered in the Vectis phosphatic concretions are summarised in Table 1 and Fig. 10. Microbial oxidation of organic matter results in a well characterised sequence of processes and cement relationships. As organic matter is buried, and pore water oxygen consumed, anaerobic bacteria continue the degradation process. First nitrogen, then manganese, iron and sulphate digesting bacteria use buried organic matter for respiration (Curtis, 1977; Berner, 1980; Berner and Berner, 1996; Ulrich et al., 1998). The ironreducing bacteria have the greatest depth range of these, and iron is frequently the most abundantly available of the oxidising agents (Berner, 1980). Accumulation of sufficient dissolved phosphate in sediment to precipitate a nodule requires a greater concentration and supply of phosphate than occurs in normal seawater (Lucas and Prevot, 1991). The presence of abundant biogenic phosphate in both bones and, to a lesser extent in organic matter, will have acted as a focus for dissolution and reprecipitation of phosphate, probably as carbonate-rich fluorapatite (CARFAP), this being the stable phosphate mineral in marine environments (Lucas and Prevot, 1991). Release of phosphate into the porewater continues as long as organic matter is present to be oxidised, permitting the gradual cementation of cavities within the nodule. The nodule still contains cavities, and it is likely that at the 
time of precipitation of pyrite, siderite and baryte, that it was still sufficiently porous and permeable for fluid communication with seawater, and supply of dissolved sulphate, carbonate, metal cations. Under reducing conditions, sulphate-reducing bacteria will, with organic matter as the electron donor, reduce pore water sulphate, and iron-reducing bacteria will reduce dissolved iron oxides and hydroxides. If sufficient of both reduced species are present pyrite will precipitate (Berner, 1980). This is consistent with the pyrite having formed after the apatite but before the siderite or baryte. Sulphate concentration in freshwater is characteristically low (Livingstone, 1963), and would have been the limiting factor in pyrite precipitation rather than iron availability.

Products of manganese reduction are rarely observed in the rock record, but where water sulphate content is low or exhausted and sufficient carbonate, iron and manganese are available in solution, manganese-bearing siderite will precipitate; most commonly where sedimentation rate is very low (Huggett 1993). The Mn-bearing siderite in the Cowleaze Chine Member nodules has enclosed corroded pyrite, indicating that it post-date the pyrite, however manganese reduction occurs in the sub-oxic zone, above the zone of iron and sulphate reduction. This timing may indicate partial exhumation of the fish and other organic remains, and would account for the pyrite enclosed in siderite being corroded.

The remainder of the cements are associated with precipitation in the oxic zone, implying that exhumation continued after siderite formation. This is entirely consistent with deposition in an ephemeral lake or lagoon. As a consequence of lowered water level, the fish and plant organic remains became exposed sub-aerially, causing desiccation and possibly formation of evaporite minerals within the fish body cavity. However this is entirely conjectural as no trace of any evaporite minerals remains.

Replacement of bioclasts and cementation of sediment by apatite is associated with fish assemblages already rich in phosphate in the form of fish bones and hard tissue (Martill, 1998; Allison \& Bottjer, 2011). Phosphatisation requires abundant organic matter, low pH and dissolved calcium and phosphate (Lucas and Prevot, 1991), that in this instance are most likely derived from dissolution of the amorphous apatite component of the decaying fish. The radial fibrous crystals of apatite may be mimicking primary structure or pseudomorphing hypothetical evaporite cement.

When considering the formation of baryte in sediments it is invariably easier to account for the sulphate than the $\mathrm{Ba}^{2+}$ ions. Moreover the low solubility of baryte means that for a significant volume of it to precipitate, as in the Cowleaze Chine nodules, necessitates mixing of the $\mathrm{Ba}^{2+}$ ions with the sulphate after, in this instance, oxidation of pyrite, not during oxidation. Lacustrine baryte is associated with bacterial oxidation and reduction of sulphate, and 
a close link between bacterial mats and baryte has been observed (e.g. Bonny and Jones, 2008; SanzMontero et al., 2009). In the environmental setting envisaged for the Cowleaze Chine it is quite conceivable that both reducing and oxidising bacteria were present in the decaying fish depending on the state of burial. $\mathrm{Ba}^{2+}$ ions are strongly adsorbed by clays, oxides and hydroxides, particularly in temperate humid climate zones (Kabata-Pendias, 2001). However, $\mathrm{Ba}^{2+}$ ions may be released from clays and feldspars under reducing conditions (Zang et al., 2001; Atun and Bascetin, 2003; Jennings et al, 2014, 2015). Re-introduction of oxygen to the sediment (i.e. exhumation) will have resulted in oxidation of the pyrite, with the sulphate once more being released into solution, making it available to react with the $\mathrm{Ba}^{2+}$ ions to form baryte.

An alternative mechanism involves pedogenic formation of baryte. Pedogenic baryte appears to precipitate at the redox boundary, while $\mathrm{Ba}^{2+}$ ions can be mobilized and concentrated in Btg soil horizons $\sim 100-160 \mathrm{~cm}$ below the surface (Jennings and Driese, 2014). Jennings and Driese (2014) conclude that pedogenic baryte is favoured by warm soil temperatures, with both sulphur-reducing and sulphur oxidizing microbes, alternating wet and dry seasons that allow alternating redox conditions, a low-gradient landscape, parent material that contains barium- and sulphur-rich constituents; and a longlived, stable landscape. This scenario is also consistent with the sedimentary environments of the Cowleaze Chine Member, and we have no reason to prefer one mechanism over the other.

Green clay granules form at, or a few $\mathrm{cm}$ below, the sediment water interface, close to the redox boundary. They form where sedimentation is slow, by replacement of pseudofaecal pellets that characteristically contain the organic matter and iron oxides required for the serpentinization process (Huggett et al., 2010, Huggett et al., 2015). The presence of green granules in the desiccation cracks of the Cowleaze Chine Member is consistent with formation of the granules during flooding of the surface by marine or brackish water. The dispersed green clay in V3 is interpreted as reworking of clay from desiccation cracks into sand. The formation of the green clay post-dates the concretion cementation, if, as interpreted here, the concretions form during burial and the exhumation that also resulted in desiccation crack formation.

Conclusions.

Concretions from the Cowleaze Chine Member of the Vectis Formation in Sandown Bay have an unusual and complex diagenetic history, involving early pyrite and apatite formation, then subsequent exhumation in a desiccated lagoon. This lead to oxidation of the pyrite, and possible precipitation of evaporate minerals, now replaced by apatite. Later cementation by $\mathrm{Mn}$ rich siderite, and formation of 
baryte, completed the diagenetic history. The complexity is related to both fluctuating salinities, and desiccation history of the lagoon.

\section{Reference}

Allison, P.A. and Bottjer, D.J. 2011. Taphonomy: Process and Bias Through Time. Allison, P.A. and Bottjer, D.J. (eds.), Taphonomy: Process and Bias Through Time, 1 Topics in Geobiology 32, 17p.

Atun, G., Bascetin, E., 2003. Adsorption of barium on kaolinite, illite, and montmorillonite at various ionic strengths. Radichimica Acta 91, 223-228.

Berner, R.A. 1980. Early Diagenesis a theoretical approach. Princeton Series in Geochemistry., Princeton, New Jersey, USA., pp. 241.

Berner, E.K. and Berner, R.A (1996) Global environment: Water, air, and geochemical cycles. Geochimica et Cosmochimica Acta 60, 5157-5158

Bonny, S.M. and Jones, B. 2008. Experimental precipitation of baryte $\left(\mathrm{BASO}_{4}\right)$ among streamers of sulphur-oxidizing bacteria. Journal of Sedimentary Research 78, 357-365.

Curtis, C.D. 1977. Sedimentary geochemistry: environments and processes dominated by involvement of an aqueous phase. Phil. Trans. Royal Soc. A286, 353-372.

Daley, B and Stewart, D J. 1979. Weekend field meeting: The Wealden Group in the Isle of Wight. Proceedings of the Geologists' Association, Vol.90, 51-54.

Gale, A.S. 2012. Chapter 18: Early Cretaceous; rifting and sedimentation before the flood. In: Woodcock, N.H. \& Strachan, R.. Geological history of Britain and Ireland. Blackwells, Oxford.

Hazell, C.J. 2014. Investigation into the Vetis Formation at Sandown Bay, Isle of Wight, and Evidence for Jurassically Derived Palynomorphs in the Shepherd's Chine Member. Unpublished BSC Dissertation, University of Portsmouth, 155p.

Huggett, J.M. 1993. Petrology and diagenesis of Palaeogene clays from Ølst and Albaekhoved, Denmark. Bull. Geol. Soc. Denmark 40, 256-271. 
Huggett, J.M., Gale, A.S. and McCarty, D. (2010) Petrology and Palaeoenvironmental significance of authigenic iron-rich clays, carbonates and apatite in the Claiborne Group, Middle Eocene, NE Texas. Sedimentary Geology 228, 119-139.

Huggett, J.M., Burley, S.D., Longstaffe, F.J, Saha, S. and Oates, M. . (2015) The nature and origin of authigenic chlorite and related cements in Oligo-Miocene reservoir sandstones, Tapti gas fields, Surat Depression, Offshore Western India. Journal of Petroleum Geology 38, 383-409.

Insole, A, Daley, B, and Gale, A. 1998. The Isle of Wight. Geologists' Association Guide. No. 60. (The Geologists' Association.)

Jennings, D. S., Driese, S. G. 2014. Understanding baryte and gypsum precipitation in upland acid-sulfate soils: An example from a Lufkin Series toposequence, south-central Texas, USA. Sedimentary Geology, 299; 106-118

Jennings, D. S., Driese, S. G and Dworkin, S.I. 2015. Comparison of modern and ancient baryte-bearing acid-sulphate soils using micromorphology, geochemistry and field relationships. Sedimentology 62, 1078-1099.

Kabata-Pendias, A., 2001. Trace Elements in Soils and Plants. CRC Press, New York, 432 pp.

Kerth, M and Hailwood, E A. 1988. Magnetostratigraphy of the Lower Cretaceous Vectis Formation (Wealden Group) on the Isle of Wight, southern England. Journal of the Geological Society, Vol.145, 351360.

Martill, D. M. 1988. The Preservation of Fish in the Cretaceous Santana Formation of Brazil. Palaeontology, 31 (1); 1-18

Livingstone, D.A. 1963. Chemical composition of rivers and lakes. Data of Geochemistry .ed. M. Fleisch. Geol.Surv. Prof. Paper. 440-G.

Lucas, J., Prevot, L. E. 1991. Phosphates and fossil preservation. In P. A. Allison \& D. E. G. Briggs (eds), Taphonomy: Releasing the data locked in the fossil record. New York: Plenum. 
Osborne White, H J. 1921 [1994 reprint]. A short account of the geology of the Isle of Wight. Memoirs of the Geological Survey of Great Britain. 235pp. [HMSO].

Radley, J. and Allen, P. 2012. The Wealden (non-marine Lower Cretaceous) of the Wessex Sub-basin, southern England. Proceedings of the Geologists' Association 123,

319-373

Radley, J., Gale, A.S. and Barker, M.J. Derived Jurassic fossils from the Vectis Formation (Lower Cretaceous) of the Isle of Wight, southern England. Proceedings of the Geologists' Association 109, 8191Allison, P. A, Bottjer, D. J. (eds) 2011. Taphonomy, Second Edition. Process and Bias Through Time. Topics in Geobiology, 32.

Sanz-Montero, M. E., Rodríguez-Aranda, J. P., García del Cura, M. A. 2009. Bioinduced precipitation of baryte and celestite in dolomite microbialites. Examples from Miocene lacustrine sequences in the Madrid and Duero Basins, Spain. In Limnogeology: Ancient and modern tales of an evolving Earth, Sedimentary Geology, 222(1); 138-148.

Stewart, D J. 1981. A field guide to the Wealden Group of the Hastings area and the Isle of Wight. 3.13.32 in Elliott, T (Editor), Field Guides to Modern and Ancient Fluvial Systems in Britain and Spain, International Fluvial Conference, Keele University, UK.

Stewart, D.J., Ruffell, A., Wach, G., Goldring, R., 1991. Lagoonal sedimentation and fluctuating salinities in the Vectis Formation (Wealden Group, Lower Cretaceous) of the Isle of Wight, southern England. Sedimentary Geology 72, 117-134.

Ulrich, C.A., Martino, D., Burger, K., Routh, J. Grossman, E.I. Ammerman, J.W. and Suflita, J.M. (1998) Sulfur Cycling in the Terrestrial Subsurface: Commensal Interactions, Spatial Scales, and Microbial Heterogeneity. Microbial Ecology 36, 141-151.

Zang, P.-C. et al., 2001. Adsorption of barium (II) on montmorillonite: an EXAFS study. Colloids and Surfaces A: Physicochemical and Engineering Aspects, 190: 239-249. 
Figures

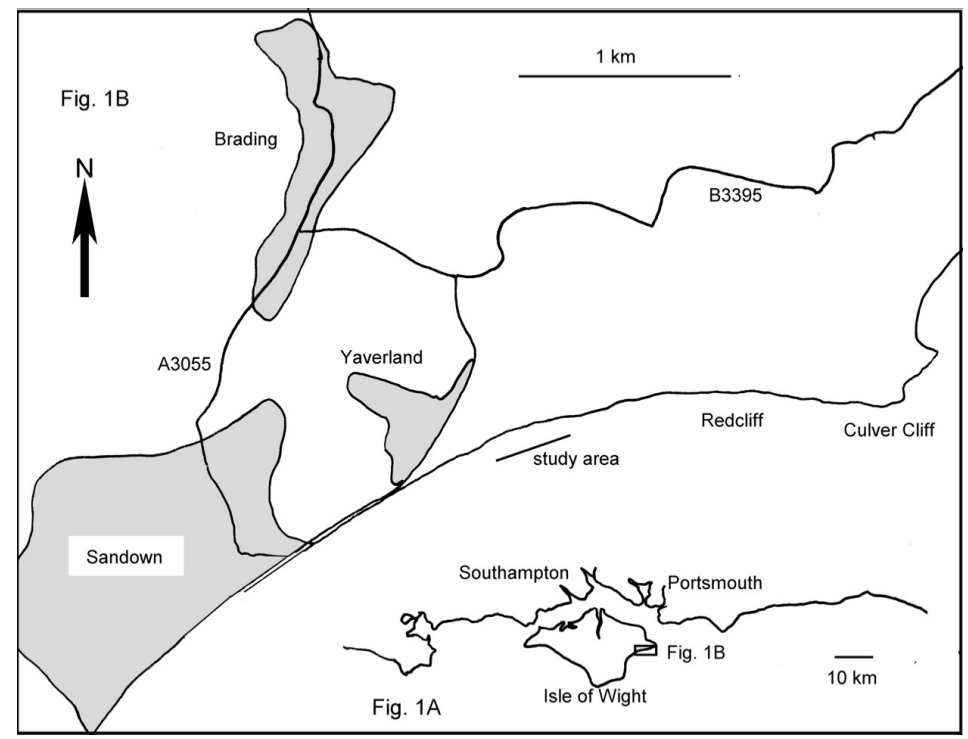

Fig. 1. location map showing the position of Yaverland, where the samples were obtained from the foreshore.

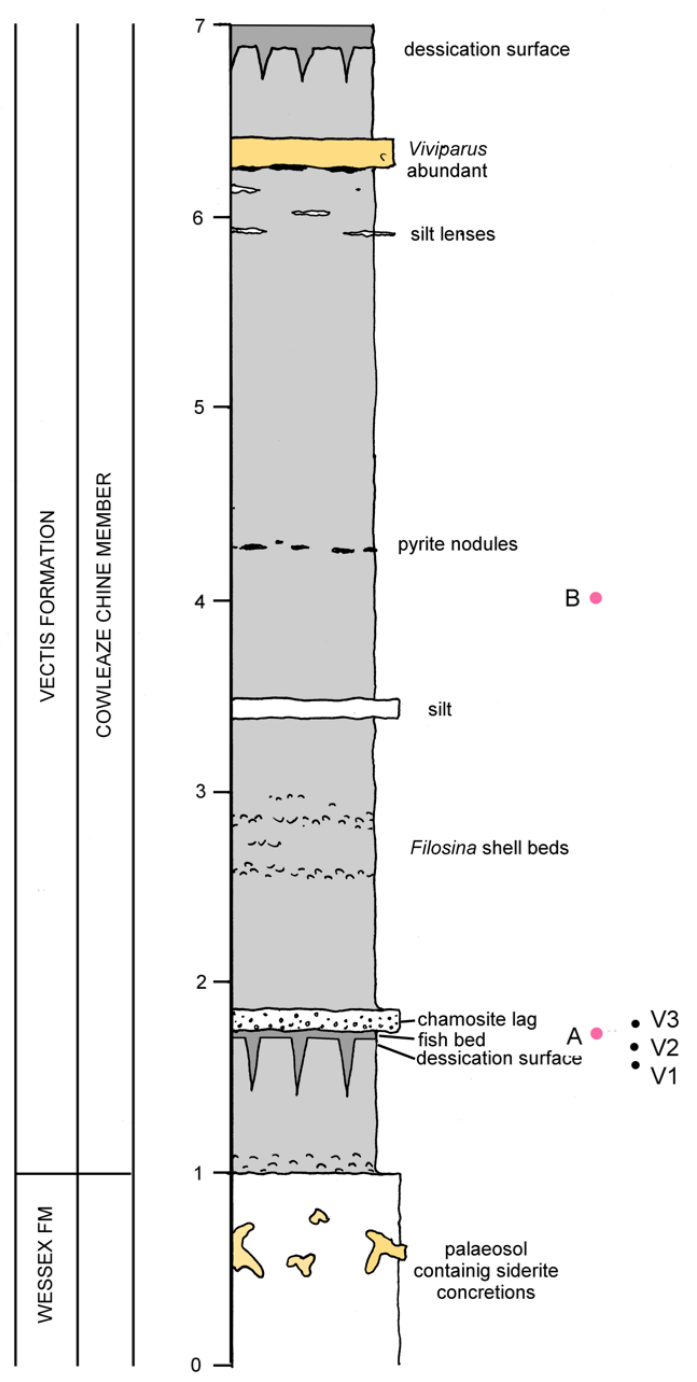

Fig. 2. Stratigraphy of the lower part of the Cowleaze Chine Member, Yaverland, Isle of Wight. Siderite concretions are coloured yellow. " $A$ " and " $B$ " denote the horizons from which the nodules were probably derived (A) and obtained (B). V1-3 = clay samples. 


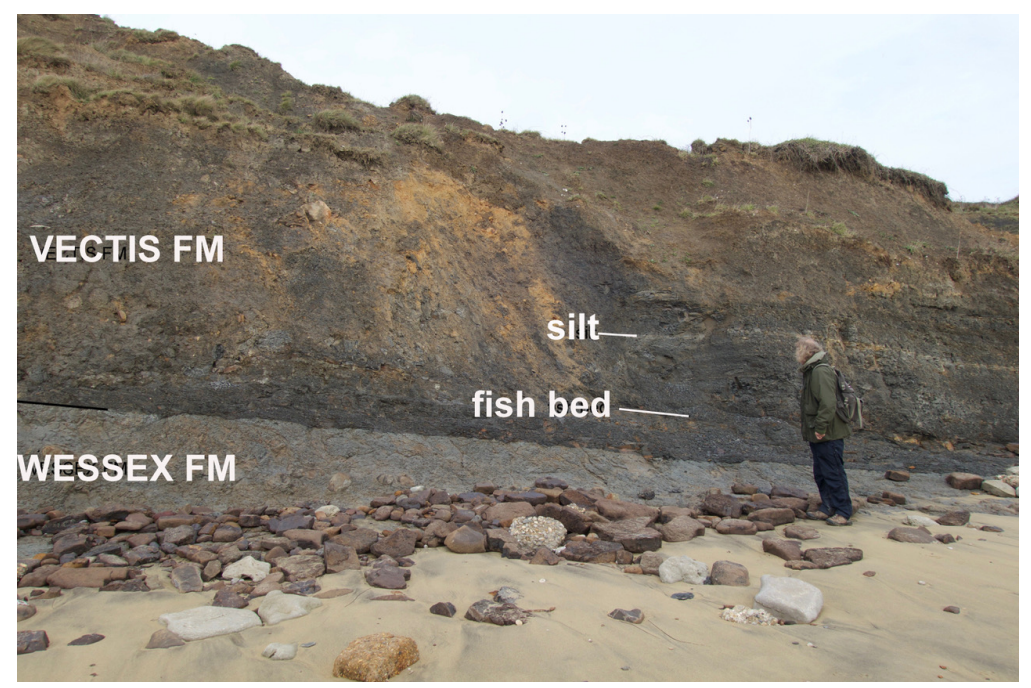

Fig. 3. Field photograph of the cliff showing the Vectis and Wessex formations showing the fish bed and silt horizon indicated in Fig. 2. 1.8m tall man for scale. Yaverland, Sandown, Isle of Wight.

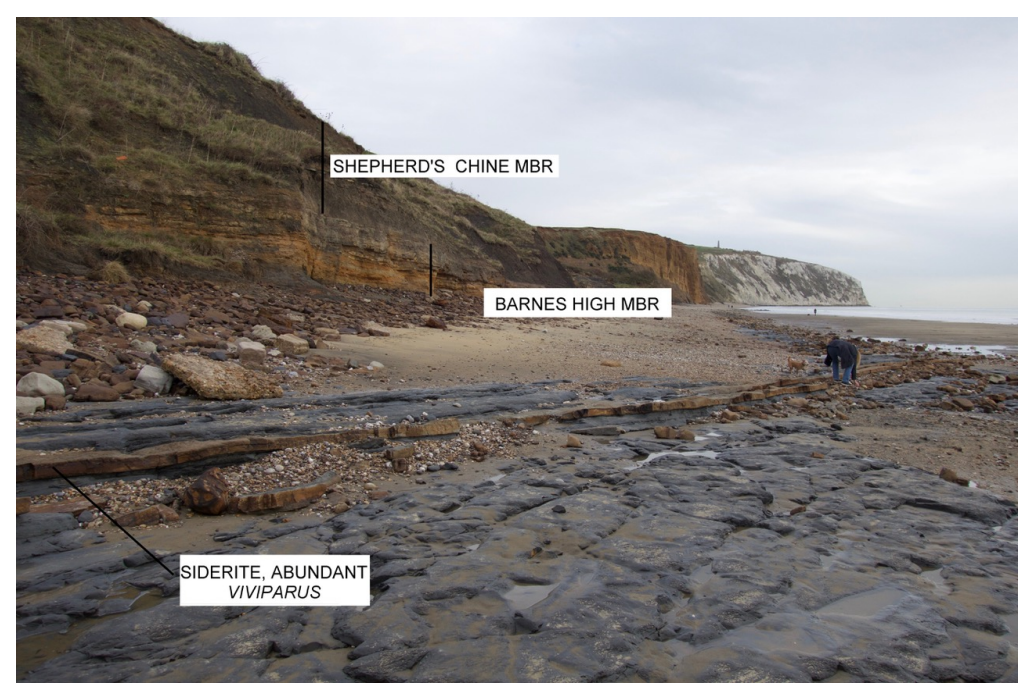

Fig. 4. Field photograph of the cliff showing the Shepherds Chine and Barnes High members, Yaverland. The wave but platform in the foreground exposes the siderite-cemented bed with abundant Viviparus.

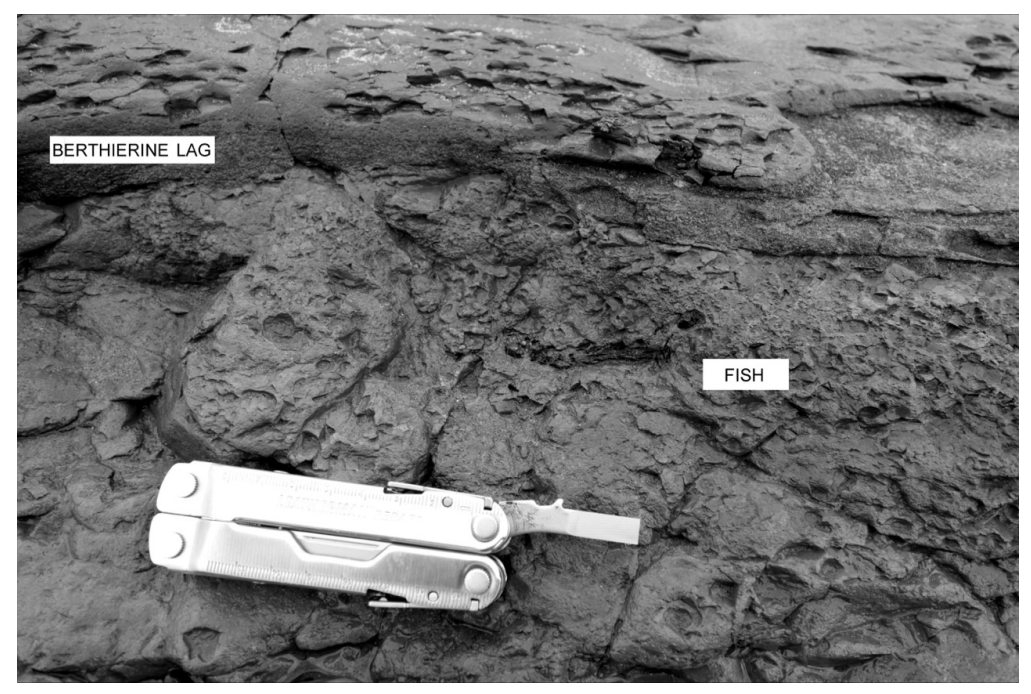

Fig. 5. Overhead view showing the berthierine lag (V3) overlying the clay bed containing partial and disarticulated fish (Lepidotes sp.), an individual is marked by an arrow. 


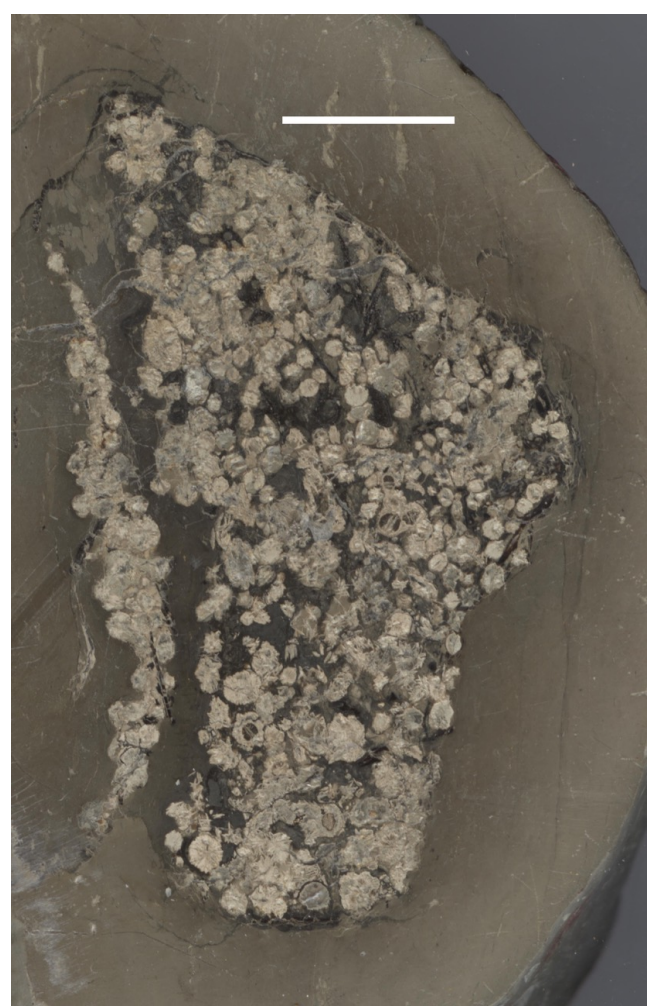

Fig. 6. Cut and polished section of nodule 1 . Scale bar $1 \mathrm{~cm}$.

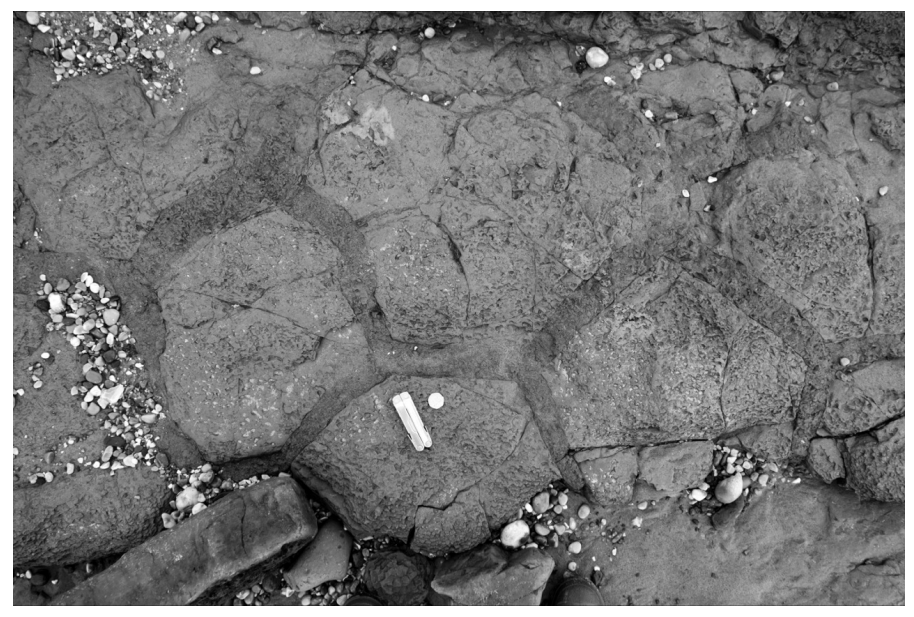

Fig. 7. Overhead view of the desiccation polygons at $0.8 \mathrm{~m}$ on fig. 2 , with a $50 \mathrm{p}$ coin for scale. Basal Cowleaze Chine Member, Yaverland. 

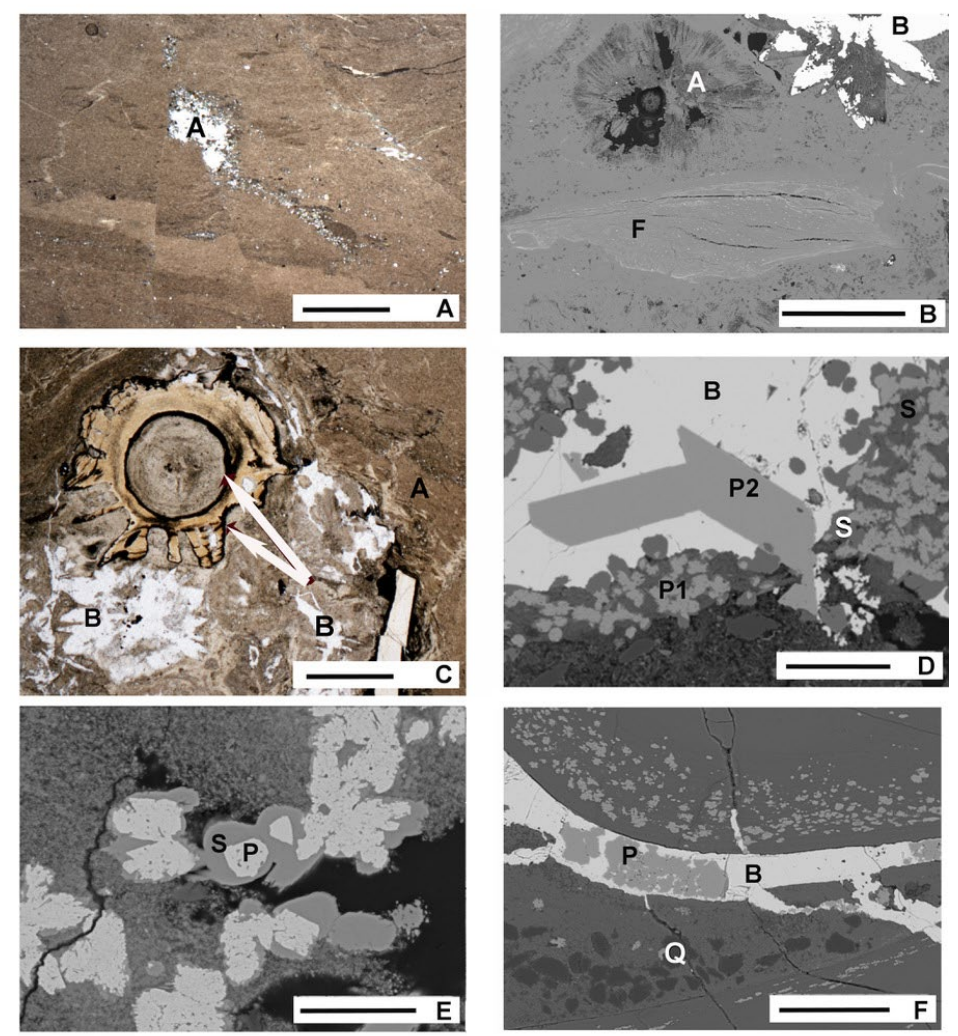

Fig. 8. Micrographs of nodule A.

A. Plane-polarised light optical microscope image of apatite $(A)$ cementing syn-sedimentary closed fractures in the sediment. Scale bar $=1 \mathrm{~mm}$.

B. BSEM image of haversian canal cavities cemented by cryptocrystalline apatite (A) mimicking a previous fibrous structure. In turn, the fibres of apatite have been partly pseudomorphed by baryte (B). A fish scale $(F)$ is also shown. Scale bar $=1 \mathrm{~mm}$.

C. Plane-polarised light optical microscope image showing pyrite $(P)$ on both the outer surface of a fish bone and on the interior walls of the haversian canal cavity (arrows). The nodule matrix is cemented by microcrystalline apatite (A). Fibrous crystals are baryte (B). Scale bar $=1 \mathrm{~mm}$.

D. BSEM image of microcrystalline pyrite aggregates (P1) and larger pyrite crystals (P2) that were probably cubes prior to partial replacement by baryte (B). Siderite (S) encloses the microcrystalline pyrite. Scale bar $=100 \mu \mathrm{m}$.

E. BSEM image of microcrystalline pyrite that is pitted as a result of partial oxidation during brief exhumation. Following oxidation and re-burial, $\mathrm{Mn}$ siderite $(\mathrm{S})$ has overgrown the pyrite. Scale bar = $40 \mu \mathrm{m}$.

F. BSEM image of a fracture within the apatite nodule $(A)$ that has been cemented by pyrite $(P)$ and baryte (B). The textural relationship suggests that the baryte has replaced or overgrown the pyrite. Quartz silt $(Q)$ is also shown. Scale bar $=100 \mu \mathrm{m}$. 

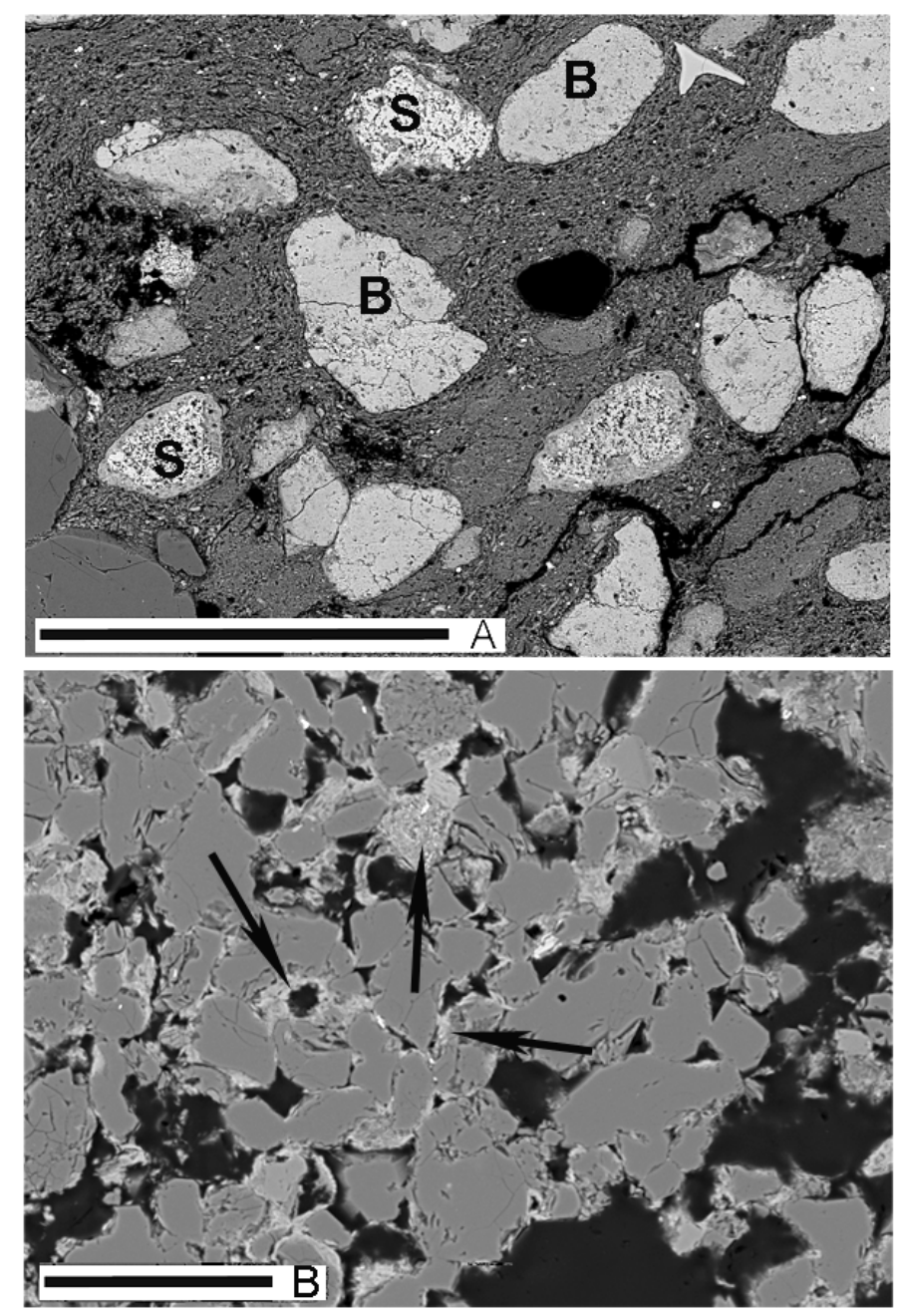

Fig. 9. Micrographs of berthierine-rich clay.

(A) BSEM image of berthierine-rich granules (B) and granules partly replaced by siderite (S) from bed V2.

Siderite appears paler than berthierine. Scale bar $=100 \mu \mathrm{m}$. (B) BSEM image of sand with intergranular, reworked berthierine-rich clay (arrows) in the berthierine lag, a few $\mathrm{cm}$ above the two beds containing berthierine granules, scale bar $=600 \mu \mathrm{m}$. 


\section{Time}

\section{pyrite}

exhumation

pyrite oxidation

Mn siderite

evaporites?

baryte

\section{berthierine}

Fig. 10. Paragenetic sequence for the authigenic components of the Lower Vectis Formation.

Tables

1. Diagenetic summary, indicating the approximate depths of the processes that resulted in the nodule cements, and the dissolution processes that contributed to the mineralisation.

\begin{tabular}{llll}
$\begin{array}{l}\text { Burial depth for } \\
\text { precipitation }\end{array}$ & Diagenetic Zone & $\begin{array}{l}\text { Mineral } \\
\text { precipitated }\end{array}$ & dissolution \\
\hline o-10ocm? & $\begin{array}{l}\text { oxic to sulphate reduction } \\
\text { then back up to oxic }\end{array}$ & $\begin{array}{l}\text { carbonate- } \\
\text { fluorapatite }\end{array}$ & $\begin{array}{l}\text { (fish bone and hard tissue, } \\
\text { organic matter }\end{array}$ \\
\hline $\mathbf{1 0 0 c m}$ & $\begin{array}{l}\text { sulphate and Fe(III) } \\
\text { reduction }\end{array}$ & pyrite & oxides, organic matter \\
$\mathbf{1 0 c m}$ & redox boundary & Mn siderite & Mn oxides, organic matter \\
$\mathbf{0 c m}$ & oxic zone & baryte & pyrite
\end{tabular}

